\title{
Az internet szerepe az alternatív mozgalmak dinamikájában
}

A társadalmi mozgalmak követeléseiket és érdekeiket tiltakozó akciókon keresztül artikulálják, s ennek érdekében minden rendelkezésükre álló erőforrást mobilizálniuk kell. Ahogy a kommunikációs szféra átalakul az internet megjelenésével, sok társadalmi mozgalom felhasználja az elektronikus kommunikációt céljai megvalósítása érdekében. A cikk szerzője az internet szerepére koncentrál az alternatív mozgalmak dinamikájában: két akcióprogram, a hazai Critical Mass és a Zengő-mozgalom internethasználatát vizsgálja. Az internet önmagában inadekvát eszköz szoros elkötelezettségek kialakítására és fenntartására, azonban alkalmas a mozgalmak üzenetének kommunikálására. A számítógéppel közvetített kommunikáció révén gyorsan lehet tömeges támogatásra szert tenni. Bár az így keletkező kötődések törékenyek, ez mégsem válik a mozgalmak kárára, hiszen a támogatók nem az egyes mozgalmakhoz, hanem a globális alternatív mozgalmi identitáshoz kötődnek.

Kulcsszavak: társadalmi mozgalmak, számítógéppel közvetített kommunikáció

\section{Szerzői információ:}

Mikecz Dániel

Politológia szakos egyetemi hallgató az ELTE Állam- és Jogtudományi Karán. 2004 és 2005 között kulturális antropológiát hallgatott az ELTE Társadalomtudományi Karán, 2006 óta a berlini Freie Universität politológus hallgatója.

E-mail: dmikecz@freemail.hu

Így hivatkozzon erre a cikkre:

Mikecz Dániel. „Az internet szerepe az alternatív mozgalmak dinamikájában”. Információs Társadalom VII, 3. szám (2007): 70-82.

$\Longrightarrow$ https://dx.doi.org/10.22503/inftars.VII.2007.3.4

A folyóiratban közölt müvek

a Creative Commons Nevezd meg! - Ne add el! - Így add tovább! 4.0 Nemzetközi Licenc feltételeinek megfelelöen használhatók. 
Mikecz Dániel

\section{Az internet szerepe az alternatív mozgalmak dinamikájában}

2003. február 15-én mintegy 11 millióan vettek részt világszerte azon a tiltakozó akción, amit az USA tervezett iraki beavatkozása ellen szerveztek aktivista szervezetek a firenzei európai társadalmi fórumon. Budapesten 20 ezer résztvevôvel folyt a tiltakozás (Pécsett 350 fáklyás felvonuló tiltakozott) - ez a létszám meg sem közelíti a római két és fél millió, a londoni másfél millió vagy a barcelonai, illetve madridi egymillió fót ${ }^{1}$ de a magyarországi arányokhoz viszonyítva jelentôs volt a résztvevốk száma, különösen, ha azt is figyelembe vesszük, hogy nem pártok által rendezett eseményról volt szó, és hogy a magyar politikai és mozgalmi kultúrában eleddig békeidóben nem volt ekkora mobilizációs ereje a politikai pacifizmusnak. Ez azonban nem az egyetlen olyan esemény volt, amit mozgalmár szervezetek rendeztek, és a magyar fốsodrú média is reagált rá.

A „Békejel” elnevezésú fáklyás akciót 2004. március 20-án már az Irak elleni támadás egyéves évfordulóján rendezték meg. Az egy évvel késóbbi „Békejel Plusz” már a nemzetközi sajtóban is szerepelt, csakúgy mint 2006-ban is. A béke kérdése azonban csak egy azok közül, amelyeket mozgalmárok sikeresen tematizáltak az elmúlt pár évben.

A Critical Mass biciklis felvonulás a fővárosi közlekedési problémákra, a Zengömozgalom pedig a környezetvédelmi kérdésekre hívta fel a figyelmet. Az utóbbi ugyanakkor a biztonságpolitikát is érintette, hiszen itt környezetvédelmi és nemzetvédelmi célok ütköztek. A Centrum Csoport a volt Úttörő Áruház után a Kazinczy utcában egy önkormányzati tulajdonban lévó ingatlant akart „elfoglalni”, az erról szóló tudósítások napokig keringtek a sajtóban.

Foglalt ház még most sincs Budapesten, de a Zengố-mozgalom elérte a célját, ahogyan a föváros illetékesei is kikérik a biciklis szervezetek képviselóinek véleményét a bicikliutak megtervezésénél. Ugyanakkor az országos médiában való megjelenés is siker, hiszen így tudják elérni a potencionális támogatókat, így hívhatják fel a figyelmet a mozgalom által tematizált problémára. A döntéshozók, a kormányzati szervek sem reagálnak az olyan tüntetésekre, amelyek nem jelennek meg a médiában, és az érintettek is legtöbbször a médián keresztül „üzennek” a mozgalom tagjainak és szimpatizánsainak (Koopmans, 2004).

Ezek a párhuzamosan megszerveződött akciók mutatják, hogy az utóbbi két évben változások történtek a magyar mozgalmi szektorban. Az alábbiakban azt a jelenséget vizsgálom, hogy az internetet hogyan használják fel, vagyis az mire alkalmazható a kollektív identitás kialakítása, az egyén identitásválasztása, a társadalmi mozgalmak diffúziója és a részvételre való mozgósítás területein. E folyamatok dinamikájának bemutatásához a Zengő-mozgalom és a Critical Mass esetét használom fel.

\footnotetext{
${ }^{1}$ http://www.indymedia.hu/cikk.shtml? $\mathrm{x}=6181$
} 


\section{Alternatív mozgalmak}

A mozgalmakat legkönnyebben az általuk elérni kívánt célok alapján lehet tipizálni: az állandóságot a folyton változó, dinamikus struktúrájú mozgalmakban a kitúzött célok határozzák meg (Szabó, 2001). Ebból a teleológiai aspektusból szemlélve a magyar alternatív mozgalmak posztmateriális értékrendjük miatt alkotnak közös csoportot. A nyugati társadalmakban a hatvanas és a hetvenes évektól kezdődóen egyre nagyobh hangsúlyt kaptak a lakosság körében az olyan értékek, amelyek az életmóddal, az életminôséggel vannak összefüggésben (egészség, egészséges környezet, béke, harmadik világgal való szolidaritás stb.). Ez a kulturális hangsúlyváltás (culture shift) a második világháború utáni gazdasági fellendülés okozta szubjektív biztonságérzet eredménye (Inglehart, 1990). Az új évezredben kibóvült a témák köre: az alterglobalizációs társadalmi mozgalmak a globalizáció témája körül szerveződnek, és olyan kérdéseket is felvetnek, mint a fair trade követelménye, a multinacionális nagyvállalatok, valamint a különféle nemzetközi kereskedelmi, pénzügyi és politikai szervezetek (WTO, IMF, Világbank, G8) szerepe és felelóssége, illetve demokratizmusa, tehát alapvetően a globális árutermelés és elosztás rendszerét bírálják. Ezek a globális problémák sarkallják közös fellépésre a globális politikai térben a globalizáció jelenlegi profiljának kritikusait (Szabó, 2004). Eközben a tiltakozó globális ellenelitek olyan értelmezési kereteket hoznak létre, amelyek nemzeti szinten is tudatosítják a globális problémákat, illetve ugyanazon a posztmateriális értékrenden belül katalizálják a helyi mozgalmak létrejöttét. Seattle után Magyarországon is megjelentek ezek a mozgalmak: a magyar alternatív mozgalmi szektor két legjelentősebb szervezete, a Védegylet és a ZÖFI (Zöld Fiatalok) 2000-ben, illetve 2001-ben alakult meg.

A Critical Mass megszerveződésénél nagy szerepe volt a budapesti biciklis szubkultúrának. Már korábban is zajlottak biciklis felvonulások Budapesten. A „Városi Biciklizés Barátai” elnevezésú szervezet 1993-ban alakult meg, és 1997 óta minden páratlan hét csütörtökén biciklis felvonulásokat szervezett a Városliget - Vörösmarty tér útvonalon. Ezekre a felvonulásokra 2-300 biciklista is elment. A hétvégeken többnapos biciklitúrákat szerveztek (Volosin, 1999). Késóbb a „Rügyecskék” egyesület szervezett ilyen felvonulásokat, ekkor már a biciklis futárokkal együttmúködve, ezek azonban nem bejelentett akciók voltak, és volt is néhány összetúzés a rendôrök és a biciklisták között. Az Off Pedál szemlére 1999-ben már 1500 résztvevố ment el. A Föld napján, az autómentes napon, illetve más, általában nyári napokon is tartottak biciklis felvonulásokat, amelyek egy része be volt jelentve elöre, de voltak nem bejelentett felvonulások is. A 2004. évi Critical Mass tehát már meglevő hagyományokra és egy tapasztalt biciklis-aktivista hálózatra támaszkodott, amely már több hasonló akciót megszervezett. Ennek az akciónak a közvetlen elốzménye az volt, hogy a budapesti városvezetés - annak érdekében, hogy ne korlátozzák túlzottan az autóforgalmat - hétvégére tette az autómentes napot, amit a legtöbb nyugati nagyvárosban minden évben szeptember 22-én rendeznek meg, függetlenül attól, hogy az hétvégére esik-e vagy sem. Ez az esemény hirtelen aktivizálta a már létezô társadalmi hálózatokat és tiltakozási potenciált. Az úgynevezett „hirtelen ható sérelmek” (suddenly imposed grievances) általában olyan, emberek által elóidézett drámai és váratlan események, amelyek felkeltik a politikai közösség érdeklődését és nagy publicitást élveznek (McAdam, 1994). 
A Zengố-mozgalom esetében ez az esemény magának a beruházásnak az elkezdése volt. A határozat a radarállomás megépítéséról már 1995-ben megszületett, a helyi hivatalokat 1996-ban tájékoztatták. Elsóként a Pécsváradi Várbaráti Kör tiltakozott a beruházás ellen, még ugyanabban az évben. A radarállomás építése azonban közel 8 éven át csupán potenciális környezetvédelmi problémát jelentett, egészen addig, amíg a munkagépek 2004-ben felvonultak a hegyre. Maga a Zengó-lista is csak 2004. február 12-én, vagyis a munkálatok megkezdéséról szóló jelentések másnapján indult.

\section{Az internet és a társadalmi mozgalmak ${ }^{2}$}

A mozgalmak természetesen nem egyik napról a másikra jönnek létre, mindig van valamilyen elốzményük, amire támaszkodhatnak. Ahogyan a társadalom szempontjából egyre relevánsabbá válik egy-egy kérdés, úgy növekszik a mozgalom is. A mozgalmi mobilizáció előfeltétele a kollektív identitás, az ellenfelek és a célok azonosítása, valamint a konfliktusban való érdekeltség (Melucci, 1996). Az internet a kollektív identitás kialakulásában, valamint magában a mobilizációs folyamatban és a mozgalom diffúziójában játszik szerepet. Bár léteznek olyan járulékos követelések, amelyek összefüggésben vannak az internettel, ezek elsốsorban az internet törvényi szabályozására, a szabad szoftverekre és a szellemi szabadalmak kérdéseire vonatkoznak, vagyis éppen azért járulékosak, mert az internet instrumentális jellegét hangsúlyozzák a mozgalmak eszköztárában. Itt ėzekkel a kérdésekkel nem kívánok foglalkozni. Számomra pontosan az az érdekes, hogy az alternatív társadalmi mozgalmak keletkezésének és fejlődésének dinamikája az internet korában - miközben céljaik alig változtak - mennyiben lett más.

Egyetlen mozgalom sem lehet teljesen elszigetelt a társadalomban: a személyes kapcsolatok és a kollektív identitás elemei hozzákapcsolják a társadalom egyes szegmenseihez, makrocsoportjaihoz. Ez a kontextus meg is határozza a mobilizáció formáját (Raschke, 1985). Csicseri Márta és Lơrincz László tanulmánya (2004) a TÁRKI 2003. februári omnibuszvizsgálatáról számol be, melynek eredményei szerint a felmérés idôpontja elótti négy hét során a teljes magyar lakosság 17\%-a használta az internetet, vagy küldött e-mail üzenetet. Ez az arány a diplomások körében $46 \%$, az érettségizettek között pedig 31\% volt. A 18-30 évesek 44\%-a, a Budapesten élók 32\%-a, a megyei jogú városok lakosainak $25 \%$-a használta a fenti formák valamelyikét a kérdéses intervallumban. Ezekre az adatokra is támaszkodva, valamint kutatásaik és egy másik felmérés ${ }^{3}$ alapján a szerzók azt állapították meg, hogy Magyarországon a környezetvédelmi mozgalmak esetében mind a támogatók, mind a mozgalmárok - szociokulturális mintáik alapján-kiemelt internetfelhasználók, vagyis körükben az internet gyakran használt és elterjedt kommunikációs csatorna.

Nem vitás, hogy a társadalmi mozgalmak felhasználják az olyan új kommunikációs eszközöket, mint az internet és a mobiltelefon, de abban már vita van az internetet és a mozgalmakat kutató tudósok között, hogy a 20. század végén és a 21. században a moz-

\footnotetext{
${ }^{2}$ Magyarországi mozgalmak és az internet kapcsolatáról lásd még: Szabó, 2005; Porubcsánszki-Szolnoki, 2004; Csicseri-Lörincz, 2004; Gerhardt, 2004.

${ }^{3}$ Pickvance, 1997.
} 
galmak dinamikájában bekövetkezett változások mennyiben az új technológiai eszközök következményei, és mennyiben függetlenek tôlük.

Az internettel kapcsolatos tudományos diskurzusban két tézis, a technológiai determinizmus és a megerósités tézise áll szemben egymással (Kiss-Boda, 2005). A technológiai determinizmus szerint az új médiumok függetlenül fejlődnek, és a társadalom csak követheti ezt a fejlődést, vagyis az új technológia alakítja ki a társadalmi mozgalmak új mobilizációs, szervezeti formáit. A megerôsítés tézise szerint viszont az internet nem alakítja át a meglévố hatalmi viszonyokat, hanem megerôsíti óket.

Charles Tilly (2004) azt állítja, hogy a társadalmi mozgalmak jellemzói sokkal inkább a társadalmi-politikai kontextus változásainak eredményei, és az új médiumok (a 19. és a 20. században a telegráf, a telefon, a rádió és a televízió, majd a 20. század végén az internet) egyrészt megkönnyítik a már eleve kapcsolatban lévô aktivisták kommunikációját, másrészt kizárják azokat, akik az adott médiumokhoz nem tudnak hozzáférni.

Véleményem szerint ahhoz, hogy a társadalmi cselekvést, a mozgalmakat internetes tevékenységük segítségével vizsgáljuk, nem kell állást foglalni a technológiai determinizmus, illetve a megerôsítés tézisei között folyó vitában, hiszen a mozgalmak internethasználata tény, az pedig, hogy mi mire volt hatással, nem érdekes abból a szempontból, hogy végül mire és hogyan használják a mozgalmak az internetet.

\section{Kollektívidentitás}

Az identitás kérdése a posztmateriális értékek megerôsödésével egy idóben és vele összefüggésben válik egyre fontosabbá. Ezt többek között a különféle szekták, kisegyházak, életmódcsoportok megjelenése is jelzi. Manuel Castells (1996) szerint a kilencvenes évek trendje az, hogy a politika és a társadalmi cselekvés már a fố identitások köré van felfúzve, az információs társadalomra jellemző az identitás mint szervezőelv kiemelkedése. A hagyományos intézmények delegitimációja, a szervezetek kiüresedése, a fố társadalmi mozgalmak eltûnése és az efemer kulturális benyomások hatására az identitás a célok fó forrásává vált. Az identitás ugyanis a tapasztalat és egyben a célok forrása is, általa tudnak a társadalmi szereplók értelmes célt adni törekvéseiknek, ami meghatározza tevékenységüket.

Az identitás mindig konstruált, és a társadalmi cselekvés szempontjából a lényeg éppen az, hogy nem strukturális adottságról van szó, ugyanis az identitás változik, a cselekvésben formálódik. A kollektív cselekvés olyan szimbolikus célokat alkot, amelyeket a mozgalom támogatói fel tudnak ismerni és össze tudnak kötni saját énjükkel, szubjektív identitásukkal. Magában a kollektív cselekvésben, az önkéntes akciókban való részvétel is az identitásszükséglet kielégítése érdekében történik (Melucci, 1996). A mozgalmak tulajdonképpen azzal fizetnek a támogatóknak, hogy részesei lehetnek a mozgalom által kialakított kollektív identitásnak.

Ez a kollektív identitás reflektál a környezetére, befolyásolja annak kialakítását, hogy mit gondol a külvilág a mozgalomról, illetve maga a mozgalom mit gondol magáról. Alberto Melucci (1996) szerint a kollektív identitás elôször is feltételezi a társadalmi aktorok önreflexióra való képességét. Ennek az a lényege, hogy a szereplók elhelyezik magukat a társadalmi kapcsolatrendszerben, s ez persze feltételez egyfajta minimális 
kölcsönös elismerést a mozgalmak, a hatóságok és a harmadik szereplók között. Azután természetesen meg kell különböztetni a mozgalmi identitást a többitól, szükség van a határok meghúzására, különböző stiláris jegyek és az úgynevezett „alternatív helyek” segítségével (Johnston-Larana-Gusfield, 1994). Az identitás kérdése mobilizációs tényezố is lesz, ahogyan ezt a házfoglaló mozgalom is mutatja. A házfoglalás célja olyan alternatív helyek kialakítása, amelyek egyrészt a késóbbi mozgalmi aktivitás infrastruktúráját adják, másrészt a közösséggel való azonosulást segítik a különbözố kulturális és politikai rendezvények révén.

Castells (1997) az identitásépítés három fajtáját és eredetét különbözteti meg: a legitimáló identitást a hatalom birtokosai hozzák létre hatalmuk biztosítása érdekében, a rezisztens identitást a társadalom perifériáján lévốk alakítják ki a hatalommal szemben, a domináns intézményektól való elhatárolódás megerốsítése és az értékítélet megfordítása mellett, míg a projektidentitás a társadalmi struktúra gyökeres átalakítására irányul, új identitás kialakításával. Ezeken az identitásokon keresztül különbözó kontextusokban jelenik meg a hatalom, az állam. A politikai tiltakozás a rezisztens és a projektidentitás talaján jön létre.

A két magyar mozgalom esetében, úgy gondolom, hogy ez az állítás inkább a Critical Massra igaz, ugyanis a Zengó-mozgalom inkább a civil társadalomban gyökerezik, mutatja ezt a mozgalomban részt vevő egyesületek és szervezetek sokasága, míg a Critical Mass, ahogyan azt már fentebb említettük, inkább a fővárosi biciklis szubkultúrából nốtt ki. Igaz ugyanakkor, hogy a Zengő-mozgalom nem egységes ilyen szempontból. A sok helyi kezdeményezés, lokális civil szervezet mellett megjelennek a Zengő-konfliktusban az ellenálló közösségek felól érkező aktivisták is, akik számára az ügy a globalizáció jelenlegi logikája által gerjesztett konfliktusok része.

Az identitásépítés a társadalmi mozgalmak esetében az értelmezési keret (frame) révén történik. A frame segítségével értelmezik egy mozgalom résztvevôi a körülöttük lévố társadalmi valóságot. A frame interpretációs séma, ami a mozgalom céljai érdekében szelektálja és egyszerúsíti a különböző eseményeket, szituációkat, és értékeli az egyes szereplóket (Snow-Benford, 1992). Ez a folyamat permanens, megmutatkozik a mozgalom állásfoglalásaiban, a skandált jelszavakban, a transzparenseken. Az antagonista értelmezési keretek segítségével tudja meghatározni a mozgalom azon cselekvók körét, amelyek ellenérdekeltek az ügy vonatkozásában (Snow-Benford, 1992). A Zengô-mozgalom esetében ez elsôsorban a radarállomás építését szervező Honvédelmi Minisztérium. A negatív címkézésben nem részesült annyira a kormány, a NATO és a hadsereg, mint a HM. Ebben az esetben könnyen azonosítható az ellenérdekelt szereplö, nem úgy, mint a Critical Mass esetében. Itt a mozgalom célja a városi biciklizés népszerúsítése, valamint a városvezetés figyelmének felkeltése a problémára, ami a mozgalmárok reményei szerint változást hozhat a várospolitikában. Bár a biciklis szubkultúrában létezik egyfajta autóellenesség, a mozgalom deklaráltan nem autóellenes. ${ }^{4}$ Nincs tehát kifejezetten azonosított ellenfél, de maga a szubkultúra elkülöníti magát a társadalmon belül, ezért is lehetett olyan nagy visszhangja a szubkultúrában a Sláger Rádióban elhangzott „vicceknek”, amelyek a biciklisták ellen irányultak.

\footnotetext{
${ }^{4}$ http://criticalmass.hu/?q=node/31
} 
A frame kialakítása természetesen nem történhet úgy, hogy ne reflektáljon már meglévô értelmezési sémákra, hiszen a mozgalmak is mindig visszavezethetóek korábbi mozgalmakhoz. A már létező társadalmi hálózatok, amelyek lehetnek korábbi szervezetek is, indikátorai a mozgalmak szerveződésének (Johnston-Larana-Gusfield, 1994). A múlt egy pillanatára vagy egy próféciára való hivatkozás erősen jellemzi a vallási mozgalmakat, de ilyen hivatkozások eloofordulnak kifejezetten politikai mozgalmaknál is (Hunt-Benford-Snow, 1994). A Zengó-mozgalmat gyakran hasonlítják a bós-nagymarosi vízlépcsố elleni tiltakozásokhoz, bár ezt a „Civilek a Zengôért” mozgalom több aktivistája tagadja. ${ }^{5}$

Az internet alkalmas ezeknek a frame-eknek a továbbadására, azonban, ahogyan azt látni fogjuk, nem lehetséges csupán az interneten keresztül szoros kötôdést kialakítani, a számítógép által közvetített kommunikáció nem alkalmas az egyén szocializációjára. Ugyanakkor a mozgalom identitásának jelképei és az uralkodó értelmezési keretek jól kommunikálhatóak az interneten keresztül.

\section{Mobilizáció, diffúzió}

Ha sikeres akar lenni egy mozgalom, el akarja érni célját, akkor mindenféleképpen meg kell gyốznie a közvéleményt igazáról, szélesítenie kell támogatóinak bázisát. A Zengố-ügy esetében, mivel az ellenérdekelt fél nem egy helyi hatóság volt, hanem a HM, csak úgy tudott sikeres lenni a mozgalom, ha országos méretủ üggyé dagad a konfliktus, és így már a nemzeti politikai térben tud nyomást gyakorolni a HM-re. Ugyanígy a biciklis szubkultúra sem tudta volna önmagában állásfoglalásra késztetni a fóváros vezetését. Egyszóval a mozgalomnak minél szélesebb körben kell tudnia mobilizálni az elérhető erőforrásokat. Eközben a kollektív aktor összegyújti és rendezi a rendelkezésére álló erőforrásokat a közös cél érdekében, az ellenérdekelt csoportokkal szemben. A mobilizációs folyamat során tulajdonképpen a mozgalom diffúziója megy végbe.

A kollektív cselekvés diffúziója során információk, identitásformák és kollektív cselekvési formák terjednek (Myers-Oliver, 1998). Ezek az elemek különféleképpen terjedhetnek szét: a társadalmi mozgalmak diffúziójával foglalkozó elméletek megkülönböztetik az erôs és a gyenge kötelékeket az adoptáló közösségeken belüli diffúziós folyamatban (Strang-Soule, 1998). Az erôs kötelékeket az interperszonális kapcsolatok alkotják. A gyakori kölcsönhatás révén információk cserélődnek ki a szétterjedő gyakorlat karakteréról és a hatásával kapcsolatos elvárásokról. A személyes ismertségeken alapuló kapcsolatháló révén gyorsan elterjedhetnek bizonyos gyakorlatok egy meghatározott közösségen belül, ami lehet egy mozgalmi szubkultúra is. Az internet ugyanakkor a gyenge kötelékek fenntartásában hatásos (Castells, 2001). Ezek a gyenge kötelékek alkalmasabbak az információk és a hírek közlésére, ugyanis az erôs szálak gyakran átfedik egymást, az egymással szoros kapcsolatban lévớ felek ugyanazon személyekkel tartanak fenn hasonló szoros kapcsolatot, ezért nem tudnak túl sok újdonságot átadni a másiknak. A gyenge kötôdések között ezzel ellentétben nincs annyi átfedés, így az ilyen

${ }^{5}$ Vay Márton (szerk.): Zengó - ökológia, politika és társadalmi mozgalom a Zengó-konfliktusban. Budapest, 2005, Védegylet. 
kötelékek révén érkező információ újdonságnak hat. Mivel ezeknek a csatornáknak a kapacitása korlátozottabb, inkább az újságok közlésére alkalmasak, míg az erôs kötelékek inkább a szocializációt segítik eló (Strang-Soule, 1998). Az információk, az identitásformák és a kollektív cselekvés formái tehát más-más módon terjednek a különbözố szálakon. A számítógép közvetítette kommunikációra (Computer Mediated Communication, $C M C$ ) jellemzőek a „sokaktól sokakhoz” (many-to-many) típusú közlések, amelyekben elméletileg nincsenek kiemelt beszélôi szerepek. Ez kedvez a hálózatos struktúra kialakulásának.

Fentebb említettük, hogy az internet alkalmas a frame-ek továbbítására: a mozgalom identitásának jelképei, az uralkodó értelmezési keretek jól kommunikálhatóak az interneten keresztül. Erre alkalmas eszközök - többek között - a honlapokon megnyitott csevegố szobák, a képgalériák és a regisztrációs lehetôségek. A www.criticalmass.hu honlapon két felvonulás között is folyik élet, a szobákban a biciklis életmóddal kapcsolatos témákat beszélik meg a csevegók, és a biciklis hírekhez is hozzá lehet szólni. A támogatók a csevegőszobákban folyamatosan újrafogalmazzák, feszegetik, illetve megerôsítik a mozgalom értelmezési keretét, a kollektív identitást. A számítógép közvetítette kommunikáció során mindenkinek a mondanivalója megjelenik, és az anonimitás hatására a felhasználók olyan emocionális, komplex, finom kijelentéseket is tesznek, amilyeneket személyesen nem tennének (Wellmann, 1999). A képgalériákon keresztül az érdeklódók belekóstolhatnak a Critical Mass (a továbbiakban: CM) hangulatába, a regisztráció pedig valamilyen hivatalosságot ad a támogatói státusznak, elmélyíti az elkötelezettséget. A $C M$ egyik szervezóje, Kürti Gábor is kiemelte az internet jelentôségét a vele készített interjúm során:

„...[az első CM óta] annyi változás volt, hogy volt egy srác, aki honlapot is csinált, de az akkor még nem volt interaktív, hanem statikus honlap, arra föltöltöttünk mindenfélét, hogy mit akarunk, meg satöbbi, és innentól kezdve már nagyon, nagyon könnyen el lehetett érni az embereket, mert az online újságokból is mindenhol linkeltek a cikk végén, és akkor ott már a csak aznapi látogatottság 3-4 ezer körül volt, amikor a csúcson volt. [...] Ami már nagyon nagy lépés volt, hogy interaktív volt a honlap, tehát hogy bármit kérdezhettél, naponta lehetett frissíteni. [...] A grafikus, én meg a honlapkészítő srác beültünk a Szódába, és avval kezdôdött minden, hogy akkor ennek új, rendes alapot kell csinálni, és akkor ó kitalálta, hogy új logót, meg minden, és a webes srác meg a honlapot. Csak abban maradtunk, hogy ilyen blogszerú lesz, és akkor több embernek lesz joga, hogy hozzászóljon, és ezt majd igyekszünk szélesíteni.”

Az 1. ábra a www.criticalmass.hu honlap havi látogatottságát mutatja 2005-ben és 2006 elején. Jól látszik, hogy áprilisban és szeptemberben hogyan ugrott meg a honlap látogatottsága: Áprilisban naponta átlagosan 1482, szeptemberben pedig 2701 látogatást regisztráltak a honlapon. A biciklis felvonulásokat (április 22, szeptember 22.) követően nem rögtön, drasztikusan, hanem folyamatosan esett vissza a látogatottság. 


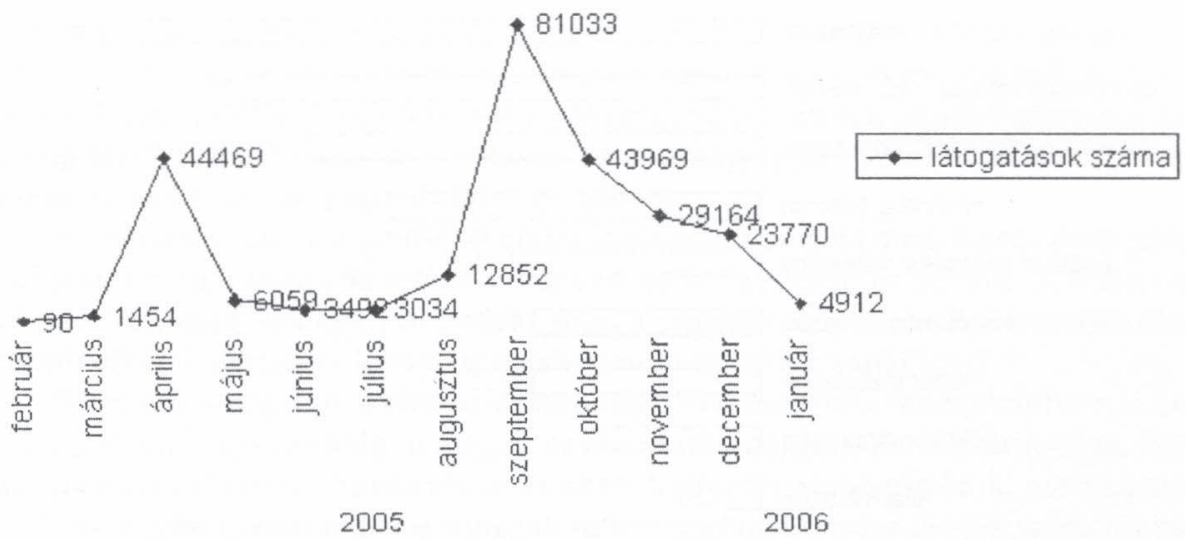

1. ábra. A www.criticalmass.hu honlap havi látogatottsága

A demonstrációkat követố hónapokban a támogatók még „visszajárnak” a honlaphoz. A kollektív cselekvés kialakít egyfajta kötődést, és a biciklis felvonulások közötti szünetekben is van még érdeklődés a mozgalom iránt. Ez a CM esetében csak a honlapon keresztül elégíthetố ki, ugyanis a köztes idôszakban valójában nincs demonstratív mozgalmi aktivitás.

A 2. ábra a Zengó-listára érkezó levelek számát mutatja. A legtöbb levél 2004 márciusában érkezett. Ekkor, a februári demonstrációk után szerveződött meg többek között a riadólánc, ami a Zengó-védók gyors mozgósítását szolgálta. A lista 2005 februárjában kezdett újból aktivizálódni. Február 15-én járt le a fakivágási tilalom, és a mozgalom tagjai tartottak attól, hogy elkezdődik a lokátor építése. 2005 júliusában pedig Vári Gyula tesztrepülése kapcsán élénkült meg a lista, tehát a Zengó-lista sem független a konkrét eseményektól. Egy évvel korábban, 2004 júniusában egyáltalán nem érkezett levél a listára, de ezen kívül is volt tizenegy olyan hónap, amikor a listára küldött levelek száma a tízet sem érte el.

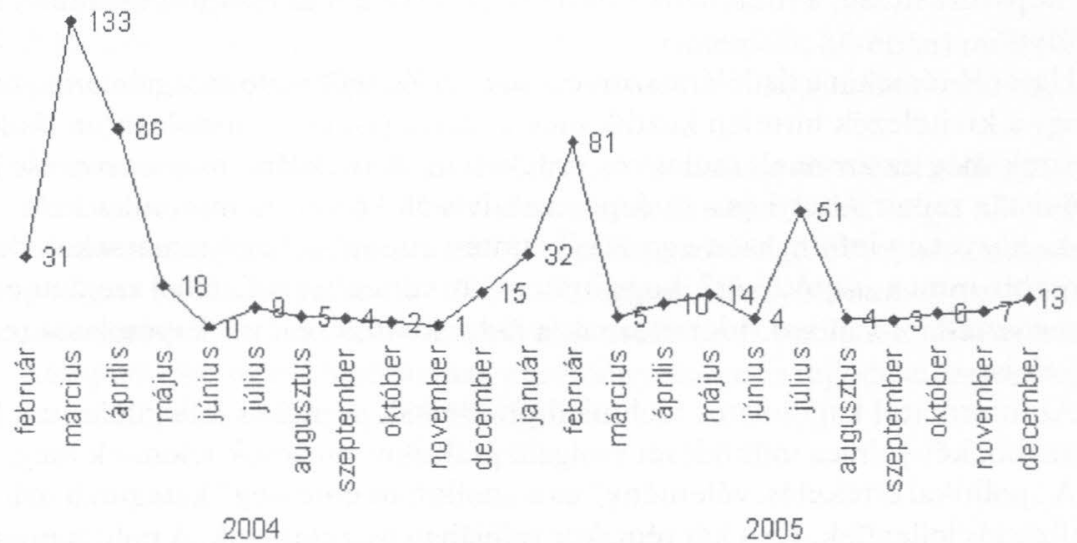

2. ábra. A Zengô-listára érkezó levelek száma havi bontásban 


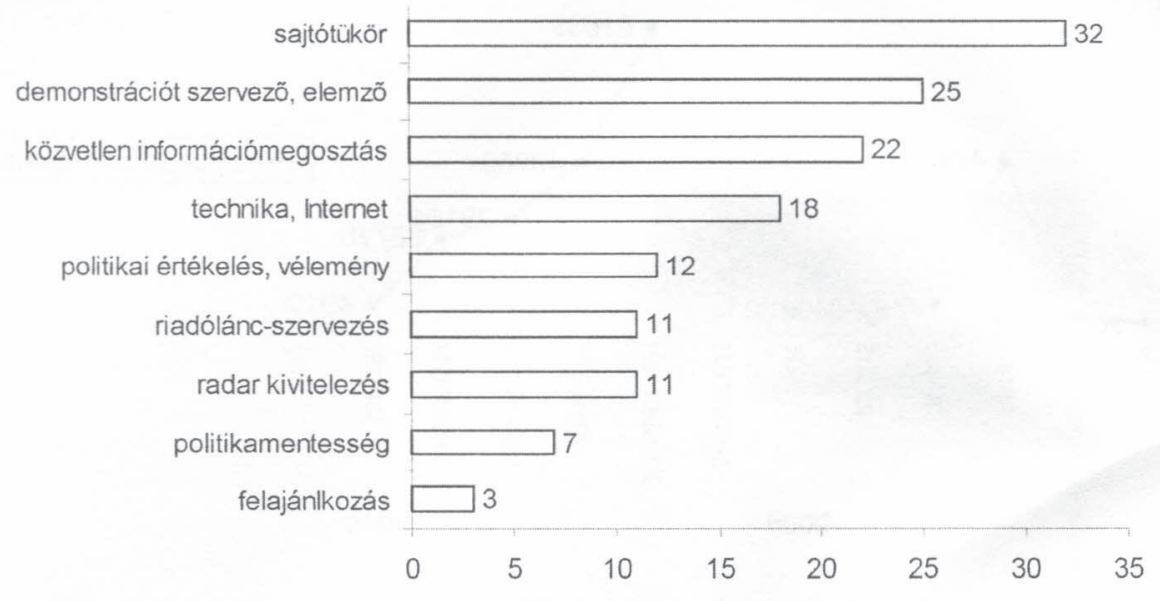

3. ábra. A Zengó-listára érkezett levelekben azonositható témakörök megoszlása, 2004. február-március

A 3. ábra azt mutatja be, hogy 2004-ben február és március folyamán bizonyos típusú témák milyen gyakran merültek fel, annak alapján különböztetve meg az egyes típusokat, hogy azok mekkora azonosulást, elkötelezettséget kívánnak meg a tagoktól. A „sajtótükör” általában online újságoknak, illetve más újságok online változatainak a „belinkelését” jelenti. Ez nem is magának az eseménynek az értékelése, hanem az újságírói interpretációé, ezért ezt nem tartom olyan típusú témának, ami erôs elkötelezettséget kívánna meg.

A második leggyakoribb tématípus már nagyobb támogatást igényel, hiszen itt egy tiltakozó tevékenység szervezéséról, illetve elemzésérôl van szó, aminek már nagyobb költségei vannak a támogatók szempontjából. Ez közvetlen politikai cselekvésre hív fel, míg a sajtószemlézés inkább csak a probléma tudatosítására szolgál. A listán azonban ebben a kategóriában is inkább az „újság”-funkció jelenik meg. A listatulajdonos szerint nem szerveződött meg tiltakozás a listán, itt már csak a tiltakozás népszerúsítése, a tiltakozók toborzása, illetve a már lezajlott esemény értékelése folyt.

Hasonló témakör a riadólánc szervezése is. A Zengốt védő mozgalmárok, tartva attól, hogy a kivitelezók hirtelen kezdik meg a fakivágást és az útszélesítést, riadóláncot szerveztek meg az azonnali cselekvés érdekében. A riadólánc megszervezése során a Zengô-listán zajlott a helyi és a budapesti aktivisták közötti kommunikáció.

A „közvetlen információmegosztás” szintén „újság”-jellegú témacsokor, de annyival erôsebb, mint a „sajtótükör”, hogy itt nem közvetlenül a médiából szerzett értesülések megosztásáról van szó. Idetartoznak a radar kivitelezésével kapcsolatos technikai kérdések is.

Az internettel kapcsolatos technikai problémák járulékos jellegúek: itt a lista zavartalanabb, kényelmes múködését szolgáló praktikus tanácsok jelennek meg.

A ,politikai értékelés, vélemény” és a „politikamentesség” kategóriái már inkább szocializációs jellegúek. Ez a két témakör valójában összetartozik. A politikamentesség igénye akkor merült fel, amikor egyre több olyan vélemény jelent meg a listán, amelyek 
egyik-másik nagyobb magyarországi politikai táborhoz köthetőek. Maga a pártpolitika a Zengơ-mozgalom egységét veszélyeztette, kétségbe vonva a résztvevôk kollektív identitását (Melucci, 1996). A kollektív identitás megvédése szintén erốsebb elhivatottságot igénylő feladat. Erre a kihívásra válaszul jelent meg egyre erốteljesebben a politikamentesség (jobb szóval: pártonfelüliség) igénye.

A „felajánlkozás” a legerôsebb elkötelezettséget kívánja meg. Kevés ilyen jellegú levél jelent meg a listán, az offline támogatók toborzása nem itt történt. A listán tehát több volt az „újság”-jellegú információ, mint a szocializációs funkciójú hozzájárulás: az erốsebb elkötelezettséget kívánó témákban nem született annyi levél.

Belépni a mozgalom online hálózatába egyúttal magába a mozgalomba való belépést is jelenti. Magyarországon maguk az alternatív mozgalmak nem láthatóak. Egyik interjúalanyom ${ }^{4}$ szerint kevés olyan konkrét kollektív akció történik, melyek alkalmából az egyén csatlakozhat a mozgalomhoz. Ezért az online belépés sokszor a valós csatlakozást pótolja. Míg a közösség inkább közös értékeken nyugszik, addig a hálózatok a társadalmi szereplók döntésein és választásain alapulnak. Ezekben az énközpontú hálózatokban (me-centered networks) viszonylag alacsony szinten van a kötelezettségvállalás, s ez törékennyé teszi az ilyen mozgalmak társadalmi támogatottságát (Castells, 2001). Azonban a globalizált alternatív mozgalmakkal kapcsolatban nem is fejezhetố ki egy általános végcél, az aktuális célok inkább rövid távú, az egyéneket közvetlenül érintố konfliktusokban jelennek meg. Ez illeszkedik a többszörös elkötelezettségek rendszeréhez (Melucci, 1996). A támogatók nem az egyes mozgalmakhoz, hanem a mozgalmak, aktivisták által kialakított kollektív identitáshoz, és azon keresztül a globális alternatív mozgalmak értelmezési keretéhez kötődnek. Alberto Melucci (1996) szerint a kortárs alterglobalizációs mozgalmakban való részvétel jellemzói az alábbiak:

1. Az ezekben kialakult szolidaritás nem mindörökre szóló, hanem az egyénnek csak az egyik lehetséges kötốdése.

2. Az elkötelezettség változó természete elmossa a szabadidő és a kötelezettségvállalás teljesítésére fordított idő közötti különbséget, és összefüggést tételez fel az önmegvalósítás és a részvétel között.

3. A mikroszinten (a rokonság, a barátok és az ismerôsök körében) múködő társas kapcsolatok alapvetô fontosságúak maradnak a mozgalomhoz való csatlakozás szempontjából.

4. Az alacsony belépési és kilépési költségek hatására a részvétel idóleges és rövid távú. A belépés feltételei kevésbé szilárdak és objektívek, míg a kilépést megkönnyíti az egyén szempontjából a csoportok sokasága, a csoport szempontjából pedig az egyén helyettesíthetôsége. A csoport elhagyása nem olyan drámai esemény, a körülhatárolt célok és a többlet-erôforrások pedig lehetôvé teszik, hogy a csoport - befogadó hálózatának eredményessége és fejlődése szempontjából szinte következmények nélkül túnjön el.

\footnotetext{
${ }^{4}$ Csillag Gábor (,Zöld Fiatalok”)
} 


\section{Konklúzió}

Az internet elterjedésével megjelentek az új médium körül forgó értelmiségi diskurzusok. Az optimista jövendölések a civil társadalom megerôsödését, hatékonyabb múködését várták. Ezek szerint az internet közelebb hozza majd az embereket, a hatalmas mennyiségú információ birtokában felelôsebben tudják kialakítani politikai véleményüket, nem lehet majd eltitkolni elólük semmit, és az internet közvetlen, olcsó elérhetốségének, valamint interaktív jellegének köszönhetốen megvalósulhat az aktívabb állampolgári részvétel. Ezzel szemben a pesszimista elörejelzések az információs dömping következtében az állampolgárok elszigetelődését és virtuális környezetükbe való bezárkózását prognosztizálták (Kiss-Boda, 2005).

Úgy tûnik, nem kell tartani a pesszimista jóslatoktól, de a túlzott optimizmus sem indokolt. Az online kapcsolatok ugyanazt a mintát követik, mint a „valós” életben, az egyén mind erôs, mind gyenge kötődéseket egyaránt fenntart. A különbség az, hogy az online kialakuló gyenge kötődések nem a szociális karakterjegyeken, hanem sokkal inkább az érdeklődésen alapulnak, és inkább „piaci” jellegúek. Az egyén maga dönti el, melyik levelezólistához, csevegószobához csatlakozik (Wellmann-Gulia, 1999). Megnó a választás lehetôsége, és csökken a csoporthoz való tartozásból eredő nyomás (Wellmann, 1999).

A társadalmi mozgalmak tekintetében az internet szerepéról a következóket tartom fontosnak kiemelni:

1. Az internet alkalmas a társadalmi mozgalmak frame-jeinek kommunikálására és a mozgalomhoz való csatlakozásra, s az online tevékenység pótolhatja az offline részvételt.

2. A kollektív identitás kialakítása azonban elsốsorban nem az interneten történik, hanem a mozgalmi szubkultúrák boszorkánykonyháiban. Ehhez erôs kötelékek, offline kapcsolatok kellenek, amelyeknek a fenntartására alkalmas az internet, de maguk az erôs kötelékek nem ott alakulnak ki.

3. Az alterglobalizációs mozgalmak esetében az egyén nem mindig azonosul teljes mértékben a mozgalommal, de a rövid életú akcióprogramok valójában a kifogásolt globális rendszer egésze ellen irányulnak, és az egyes témákban kitúzött célok a közös, globális mozgalmi identitáshoz és értelmezési keretekhez kapcsolódnak. Ezért történhetett meg, hogy az olyan nagy tüntetéseken, mint amilyenek Seattle-ben vagy Genovában zajlottak, különbözố csoportok szivárványkoalíciója jöjjön létre, és ezért lehetséges, hogy ugyanaz az egyén egy személyben Zengő-ốr és biciklis felvonuló is legyen.

4. A gyenge kötődések nem gyengítik az alterglobalizációs mozgalmakat, hanem inkább erôsítik óket, hiszen a mozgalmak éppen ezek révén, az alacsony belépési költségeknek köszönhetốen képesek olyan hirtelen mobilizálni támogatóikat.

5. Az értelmezési keretek átfedésének további elönye, hogy a valamely konfliktus kapcsán egyszer már bevont egyének késóbb, más témák felmerülésekor is mobilizálhatók. A közös értelmezési keret alapján folyamatosan megújítható a mozgalmi mobilizáció. 


\section{Irodalom}

Castells, Manuel (1996): The rise of the network society. Oxford, Blackwell Publishers.

Castells, Manuel (1997): The Power of Identity, The Information Age: Economy, Society and Culture, Vol. II. Cambridge, Ma; Oxford, UK: Blackwell.

Castells, Manuel (2001): The Internet galaxy: reflections on the Internet, business, and society. Oxford, New York, Oxford University Press.

Csicseri Márta - Lőrincz László (2004): Társadalmi mozgalmak mobilizációs és ügyképviseleti t vékenysége az Interneten. (Megjelent a Rajk László Szakkollégium „Társadalmi mozgalmak és az Internet" címmel 2004. február 20-án rendezett konferenciájának CD-ROM formában közzétett anyagában.)

Gerhardt Erik (2004): Pártok online tevékenysége - A magyarországi parlamenti pártok internetes aktivitásának elemzése. (Megjelent a Rajk László Szakkollégium „Társadalmi mozgalmak és az Internet" címmel 2004. február 20-án rendezett konferenciájának CD-ROM formában közzétett anyagában.)

Hunt, Scott A. - Benford, Robert D. - Snow, David A. (1994): Identity Fields: Framing Processes and Social Construction of Movement Identities. In: New social movements: from ideology to identity. Ed. Enrique Larana, Hank Johnston, and Joseph R. Gusfield. Philadelphia, Temple University Press.

Inglehart, Ronald (1990): Culture shift in advanced industrial society. Princeton, Princeton Univesity Press.

Johnston, Hank - Larana, Enrique - Gusfield, Joseph R. (1994): Identities, grievances, and New Social Movements. In: New social movements: from ideology to identity. Ed. Enrique Larana, Hank Johnston, and Joseph R. Gusfield. Philadelphia, Temple University Press.

Kiss Balázs - Boda Zsolt (2005): Politika az Interneten. Budapest, Századvég.

Koopmans, Ruud (2004): Movements and media: Selection processes and evolutionary dynamics in the public sphere. Theory and Society 33: 367-391. o.

McAdam, Doug (1994): Culture and Social Movements. In: New social movements: from ideology to identity. Ed. Enrique Larana, Hank Johnston, and Joseph R. Gusfield. Philadelphia, Temple University Press.

Melucci, Alberto (1996): Challenging codes: collective action in the information age. Cambridge, Cambridge University Press.

Myers, Daniel J. - Oliver, Pamela E. (1998): Diffusion Models of Cycles of Protest as a Theory of Social Movements. Elöadás, Congress of the International Sociological Association, Montreal, 1998. július. http://www.nd.edu/ dmyers/cbsm/vol3/olmy.pdf.

Pickvance, Katy (1997): Social Movements in Hungary and Russia: The Case of Environmental Movements. European Sociological Review 13(1): 35-54. o.

Porubcsánszki Katalin - Szolnoki Pálma (2004): A civil szervezetek és az Internet kapcsolata Társadalmi mozgalmi megközelítés. (Megjelent a Rajk László Szakkollégium „Társadalmi mozgalmak és az Internet” címmel 2004. február 20-án rendezett konferenciájának CDROM formában közzétett anyagában.)

Raschke, Joachim (1985): Soziale Bewegungen: ein historisch-systematischer Grundriss. Frankfurt am Main, Campus.

Snow, David A. - Benford, Robert D. (1992): Master Frames and Cycles of Protest. In: Morris, A. D. - Mueller, C. M. (eds): Frontiers in Social Movement Theory. New Haven, Yale University Press.

Strang, David - Soule, Sarah A. (1998): Diffusion in organizations and social movements: From Hybrid Corn to Poison Pills. In: Annual Review of Sociology Vol. 24: 265-290. o. 
Szabó Gabriella (2005): Internetes tömegkommunikáció. In: Kiss Balázs - Boda Zsolt (szerk.): Politika az Interneten. Budapest, Századvég.

Szabó Máté (2001): Társadalmi mozgalmak és politikai tiltakozás. Budapest: Rejtjel - (Politológia Tankönyvek).

Szabó Máté (2004): Globalizáció, regionalizmus, civil társadalom. Budapest, Századvég.

Tilly, Charles (2004): Social Movements. 1768-2004. London, Paradigm Poublishers.

Volosin Hédi (1999): A Városi Biciklizés Barátai Egyesület. In: Környezetvédelmi civil kezdeményezések Magyarországon 1988-1998: tanulmányok. Szerk. Szabó Máté. Budapest, Villányi Úti Konferencia-központ és Szabadegyetem Alapítvány.

Wellman, Barry (1999): Living Networked in a Wired World. http:/www.chass.utoronto.ca/ wellman

Wellmann, Barry - Gulia, Milena (1999): Net surfers don't ride alone: Virtual communities as communities. In: Kollock, Peter - Smith, Marc (eds): Communities and Cyberspace. New York, Routledge. 